\title{
Regional and Foreign Vocabulary in the Junior High School Bahasa Indonesia Student Books
}

\author{
M Mintowati, Kisyani, F Inayatillah, Mukzamila \\ Universitas Negeri Surabaya \\ Surabaya, Indonesia \\ mintowati@unesa.ac.id
}

\begin{abstract}
This study aims to search for regional and foreign vocabulary contained in the books of Indonesian students of SMP Grades VII, VIII, and IX. This is important because it is related to the language pride. Indonesian books should be clean from foreign and regional words. If these words are needed, it is better to use the equivalent word with the Indonesian vocabulary writing model then followed by foreign and / or regional vocabulary. If there are direct quotes using foreign or regional vocabulary, there should be an explanation or note for the direct quote. Data collection is done by reading technique, note-taking technique, and entry application. The findings of this research are (1) the regional vocabulary and dialect are 53 entries; and (2) the foreign vocabulary are 193 entries. The use of local and foreign language vocabulary is caused by reading themes. Compared to the total number of entries (10.365), the number of regional and foreign vocabulary in the books of junior high school students is 2.37. This number is small, but annoying because it has not shown a positive attitude towards Indonesian (there is still a negative attitude). It was marked by the unused of language pride rules.
\end{abstract}

Keywords—regional and foreign vocabulary; students book; language pride

\section{INTRODUCTION}

Each language has components such as phonemes, morphemes, words, phrases, clauses, and sentences. These components are assembled and used by language speakers, both oral and written for various purposes in language activities. One of the uses of language components is in junior high school students' books for Indonesian language subjects. Of these components, the vocabulary used in student books is mainly related to the words of the region and foreign words. Searching for both types of words is intended to find favorite words, namely words with high frequency of use in student books.

In developing student books, book writers try to choose the right and appropriate words [1]. This was done so that the ideas presented by the writer were understood by the reader. The author chooses words, both from the original Indonesian words and from the words of the local language or foreign words.

However, it should be noted that writing a national language textbook (Indonesian) must prioritize Indonesian vocabulary. In fact, good language textbooks are expected to be clean from foreign language and regional elements [2].

This paper aims to explore the foreign vocabulary and the area contained in Indonesian language student books for junior high schools. This is important because it is related to language pride. Indonesian books should be clean from foreign words and regions. If these words are indeed needed, you should use the equivalent words with the Indonesian vocabulary writing model first followed by foreign language and/or regional vocabulary. Besides that, foreign vocabulary writing should not be repeated because it has already been explained. If there are direct quotes using foreign or regional vocabulary, there should be an explanation or note for the direct quote.

\section{RESEARCH METHODS}

The data source of this research is the Bahasa Indonesia textbook of students of Junior High School grades VII by Harsiati et al [3], VIII by Kosasih et al (2017) [4], and IX by Zabadi and Sutejo [5]. Data in the form of foreign words and regional words contained in the three books. The data was collected by reading and note-taking techniques and using entry application. Reading techniques to find foreign vocabulary and areas in student books. Note-taking technique is used to record foreign vocabulary and areas in student books. Application entry to detect the number of entries in textbooks. Then, the data was analyzed by quantitative descriptive technique.

\section{DISCUSSION}

The data obtained appears that the foreign vocabulary is mostly used in grade VIII (92), grade VII (76), and grade IX (26). The regional language echoes are widely used in grade VII (29), grade VIII (19), and grade IX (6). This shows that the use of vocabulary from foreign languages is more popular [6]. In fact, some regional language entries are some of which are dialects that are familiar as everyday language in Indonesia. The empowerment of local languages to be able to further develop Indonesian language vocabulary need to be improved. In detail, the discussion is presented below. 
A. Regional Vocabulary in Student Book of Indonesian Language Subjects SMP

\section{TABLE 1 NUMBER OF REGIONAL IN INDONESIAN STUDENT BOOK}

\begin{tabular}{|l|c|}
\hline Students Book & Number of Regional Vocabulary \\
\hline Grade VII & 30 \\
\hline Grade VIII & 19 \\
\hline Grade IX & 6 \\
\hline Total & 55 \\
\hline
\end{tabular}

The table 1 shows the regional vocabulary used in the junior high school students are relatively fewer when compared with foreign vocabulary. In the book for grade VII students, regional vocabulary are 30 words. Then, in the book for grade VIII students there are 19 regional vocabulary. As for the grade IX book found only 6 regional vocabulary.

B. Foreign Vocabulary in Student Book of Indonesian Language Subject of SMP

\section{TABLE 2. NUMBER OF FOREIGN VOCABULARY IN INDONESIAN STUDENT BOOKS}

\begin{tabular}{|l|c|}
\hline Student Book & Number of Vocabulary \\
\hline Grade VIII & 92 \\
\hline Grade VII & 76 \\
\hline Grade IX & 26 \\
\hline Total & 194 \\
\hline
\end{tabular}

Based on the table 2, it was found that the foreign words used in Indonesian Language era more than the number of regional words. In the book of grade VII students there are 75 foreign words. Furthermore, in the book of grade VIII students used 92 foreign words, which is 91 words derived from English, 1 word from the Dutch language. In the book of grade IX students used a foreign word of 26 words. Based on these findings, the highest to lowest number of foreign language vocabulary in Bahasa Indonesia Student Books is as follows.

From the exposure that has been disclosed, the use of the entry of regional and foreign languages due to the theme of reading, e.g. technology and regional stories. The author of the book takes the source of the reading without modifying the vocabulary in the reading. In this case, the use of an entry from a foreign language may enrich the vocabulary of the student. This also applies to the use of an entry of regional languages. There is no denying that vocabulary borrowing is always done in various languages in the world as long as it is based on efforts to enrich the language. In addition, vocabulary borrowing should be managed wisely by language experts so that the vocabulary of regional languages and foreign languages is borrowed intact, absorbed, or modified.

Overall, the number of words of class Villa is 51,724 (3599 entries); grade VIII of $52,109(3,980)$; IX grade is
44,089 (2,786 entries). The total number of the book words is 147922 (10,365 entries). Compared with the total number of entries, the number of regional and foreign vocabulary in the junior high school book is 246 or $2.37 \%$.

\section{CONCLUSION}

The use of regional and foreign vocabulary in Indonesian Middle School books is evenly distributed at all grade levels. None of these books come from regional or foreign vocabulary. Compared to the total number of entries $(10,365)$, the number of regional and foreign vocabulary in Indonesian junior high School student books is 246 words $(2.37 \%)$. Although this figure is small, it is disturbing because it has not shown a positive attitude towards Indonesian language (there is still a negative attitude). The negative attitude that is intended is marked by a lack of pride rules, namely the words in Indonesian language take precedence over foreign and regional language vocabulary (such as destroying), consider other languages better / better (self-esteem)), and at the same time underestimate the quality of the language itself (Bahasa Indonesia).

The results of this study are expected to be used by (1) teachers to further improve positive language attitudes in learning, especially in the explanation of sections that use regional and / or foreign vocabulary, (2) the author of the book to reflect the results of his writing.

\section{REFERENCES}

[1] Akhadiah, Sabarti, et al, Pembinaan Kemampuan Menulis Bahasa Indonesia. Jakarta: Erlangga, 1999.

[2] Kemdikbud RI, "Undang-Undang Republik Indonesia Nomor 24 Tahun 2009 tentang Bendera,Bahasa, dan Lambang Negara, serta Lagu Kebangsaan," pp. 1-52, 2009.

[3] Harsiati, Titik et al, Bahasa Indonesia; Buku Siswa SMP/MTS Kelas VII. Jakarta: Puskur Balitbang Kemendikbud, 2017.

[4] Kosasoh, E et al, Bahasa Indonesia; Buku Siswa SMP /Mts Kelas VIII. Jakarta: Puskur Balitbang Kemendikbud, 2017.

[5] Zabadi, F and Sutejo, Bahasa Indonesia Wahana Pengetahuan. Jakarta: Puskur Balitbang Kemendikbud, 2015.

[6] Kisyani, et al, Kosakata-Baca dan Kosakata-Tulis Siswa SMP, Surabaya, 2017. 